\title{
Regulations and Guidelines for Chemigation ${ }^{1}$
}

\author{
Haimanote K. Bayabil, Kati W. Migliaccio, Jonathan H. Crane, Teresa Olczyk, and Qingren \\ Wang $^{2}$
}

\section{Introduction}

Chemigation is a process where an irrigation system is used for transport and delivery of agrochemicals, generally fertilizers and pesticides, to a crop (Haman and Zazueta 2017). Drip and microsprinkler irrigation systems are often used in chemigation. If the irrigation is properly plumbed and chemigation properly implemented, chemigation can help growers reduce chemical usage and costs because it is applied using existing irrigation distribution infrastructure. However, the irrigation system must be equipped with properly designed safety accessories to avoid contamination of water sources. In addition, it is important that the irrigation system is equipped with an injection pump designed to inject pesticides or fertilizers at a given rate so the applications are on a proper rate per unit area basis. The concentration of pesticide or fertilizer in the tank mix must be at labeled rates because application at higher concentrations could potentially damage plants and/or result in leaching the product below the root zone, which could contaminate freshwater bodies. The purpose of this document is to provide a brief overview of the regulations and some helpful guidelines for growers to follow to ensure safe handling of chemigation and to make applications at labeled rates.

\section{Chemigation Rules and Regulations}

Depending on the type of chemical being injected, there are requirements that must be met under Florida law. For any chemical product, the product label guidelines must be followed. Chemigation systems must possess an anti-siphon device that prevents possible backflow of water to the mainline. Anti-siphon devices are critical to mitigate the risk of groundwater contamination. According to Florida rules (487.064, 570.07 F.S., formerly 5E-2.30), any irrigation system used for the application of pesticides must be equipped with an anti-siphon device that ensures the water supply is protected from any potential contamination. The requirements also apply to water supply lines to pesticide mixing-loading equipment, unless the systems incorporate a physical gap between the water source and the application equipment. The anti-siphon device should have an automatic shut-off valve on the injection pump that can stop pesticides from being injected into the water system when the irrigation water flow stops. Therefore, it is unlawful for any person to apply pesticides through an irrigation system that is not equipped with an anti-siphon device as required by this rule.

1. This document is AE542, one of a series of the Agricultural and Biological Engineering Department, UF/IFAS Extension. Original publication date June 2020. Visit the EDIS website at https://edis.ifas.ufl.edu for the currently supported version of this publication.

2. Haimanote K. Bayabil, assistant professor, Department of Agricultural and Biological Engineering, UF/IFAS Tropical Research and Education Center; Kati W. Migliaccio, chair and professor, Department of Agricultural and Biological Engineering; Jonathan H. Crane, professor, Horticultural Sciences Department, UF/IFAS Tropical REC; Teresa Olczyk, director, UF/IFAS Extension Miami-Dade County; Qingren Wang, UF/IFAS Extension agent III for commercial vegetables and pesticide licensing, UF/IFAS Extension Miami-Dade County; UF/IFAS Extension, Gainesville, FL 32611.

The Institute of Food and Agricultural Sciences (IFAS) is an Equal Opportunity Institution authorized to provide research, educational information and other services

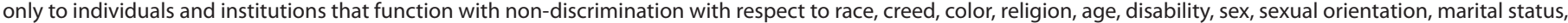

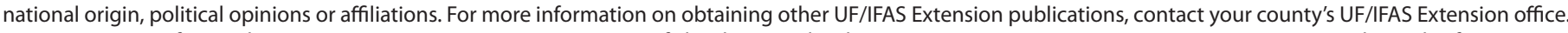
U.S. Department of Agriculture, UF/IFAS Extension Service, University of Florida, IFAS, Florida A \& M University Cooperative Extension Program, and Boards of County Commissioners Cooperating. Nick T. Place, dean for UF/IFAS Extension. 


\section{Backflow Prevention Law}

In addition, chemigation systems must conform to Florida state law (Florida Statutes 487.021 and 487.055) and Environmental Protection Agency Pesticide Regulation Notice 87-1, which requires backflow prevention regulations to be printed on the chemical label. The general rules for backflow prevention in Florida are presented in UF/ IFAS Extension Bulletins 217 and 258 (Haman and Zazueta 2017; Haman, 217). In addition, local ordinances should be checked because they may be more restrictive. Chemical injection on the suction side of a centrifugal pump is generally not permitted in Florida.

\section{Advantages and Disadvantages of Chemigation}

Chemigation has both advantages and disadvantages. Briefly, we discuss some of the advantages and disadvantages of chemigation.

\section{Advantages}

- Because the chemical is applied with irrigation water, the irrigation system facilitates a more uniform application within the area of the root zone.

- The micro-irrigation system may be automated and may be used to irrigate the crop to meet water needs and to apply agrochemicals. The injection of pesticides into the irrigation system facilitates low-cost applications of chemicals, unlike separate soil drench equipment, which requires labor and fuel to operate and distribute chemicals.

- Chemigation of chemical or fertilizer avoids additional heavy equipment traffic through the farm and, therefore, minimizes soil compaction.

- Once the chemical is injected into the irrigation system, it remains in the closed system until it is delivered to the target application area. Therefore, chemigation is a convenient system to minimize worker exposure to chemicals.

\section{Disadvantages}

- High initial investment due to the cost of the injection system infrastructure.

- Requires more knowledge and management of the irrigation system, injection of chemicals, dilution of pesticides, and discharge through the irrigation system to target sites.

- If the irrigation is not managed adequately to minimize the surface runoff and/or deep percolation of water below the rooting depth, pesticides and fertilizers may be subjected to loss (leaching). Therefore, the amount of chemical that remains within the root zone could be lower than the recommended rate, which can contribute to reduced effectiveness of the chemicals.

- There is a risk of equipment malfunction if the system is left unattended and/or mismanaged, which may result in contamination of water supply.

- Because the pesticides are diluted and distributed through the irrigation system, there is a risk of excess water applications if the crop does not require water at that time.

\section{Useful Tips for Chemigation Tip 1: Make sure your irrigation system has check valves and filters}

Check valves are components that are placed in the water flow line to allow water flow in only one direction. This prevents backflow from occurring to protect the water source and chemical sources. Check valves are required to be placed between the water supply and the chemical injection point (Figure 1).

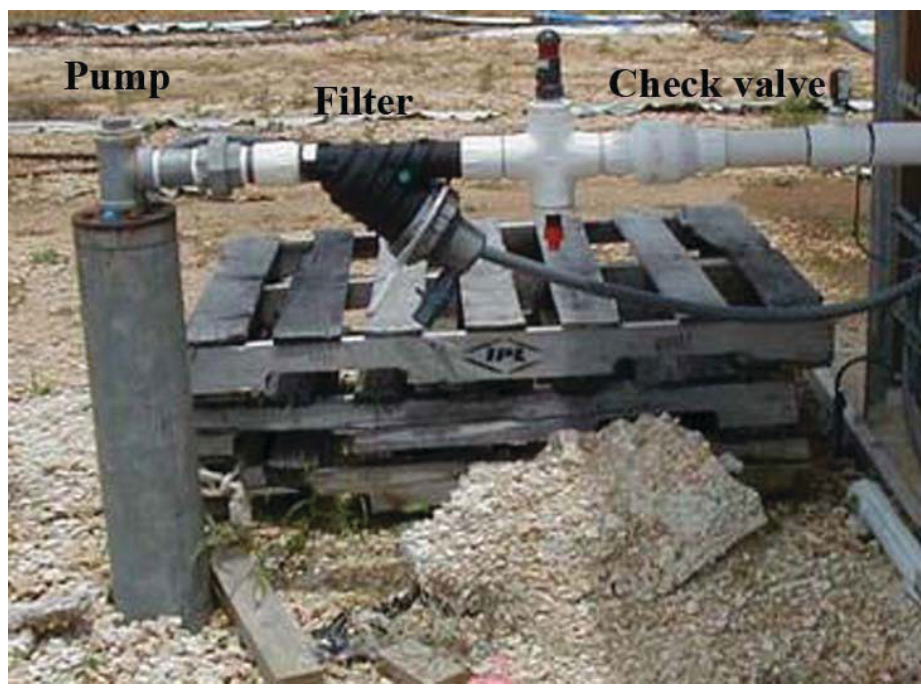

Figure 1. Water source, pump, and check valve assembly. Credits: Kati L. Migliaccio, UF/IFAS

A filter should be placed in the irrigation line. Filters are placed directly after the water source to protect the irrigation system from debris that causes clogging. Filters prevent line clogging downstream of the filter and provide easier access for cleaning unwanted debris. Other components that are required by Florida law include low-pressure drains, vacuum breakers, and chemical supply shut-off valves 


\section{Tip 2: Calculate the Quantity of Chemical Needed}

During chemigation, the chemical is injected into an irrigation line. Knowing the exact amount of chemical required is very critical (see examples in Figure 2). Calculating the correct amount of chemical required for chemigation can be done as follows:

Step 1: Determine the recommended rate of the chemical for the specific application. It should be expressed as an amount per unit area (lb/acre or gal/acre).

Step 2: Determine the acreage or number of plants on which chemigation will be applied. REMEMBER, in calculating the area, only include the planted area. This means that with drip irrigation and plastic, you would calculate the planted acreage as row length multiplied by plastic bed width multiplied by the number of rows.

Step 3: Calculate the amount of chemical needed based on information from the first and second steps. Step 1 multiplied by Step 2 .

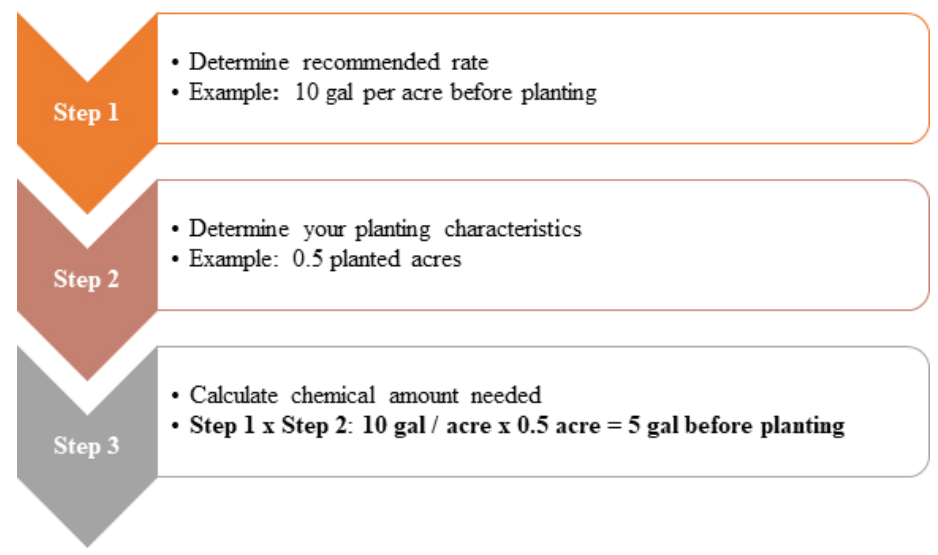

Figure 2. Example of a calculation to determine the amount of chemical needed for application in a given area.

\section{Tip 3: Calibrate your injection pump}

Chemical injectors are generally one of two types: venturi injectors or metering pump (positive displacement pump) injectors. Chemical injectors must be calibrated prior to use and periodically during use. Calibration of a chemical injector is a process for determining how much chemical is being injected at different settings. The balance between chemical injected and irrigation water flow rate is very important.

If too little water is in the chemical-and-water mixture, the following problems may occure:

- uneven chemical distribution
- high volatilization (chemical loss)

- chemical buildup in irrigation lines

- potential crop damage due to chemical concentration

If too much water is in the chemical-and-water mixture, the following problems may occure:

- dilution of the chemical below effective concentrations

- loss of chemical due to leaching and contamination of groundwater

\section{EXAMPLE: CALIBRATION OF AN INJECTION PUMP}

Calibration of a metering pump injector can be performed using the following equipment: injector, pen and paper, container marked with volumetric levels, and timer.

1. Fill the container to a known volume.

2. Set the injector to the desired rate (usually expressed on a dial as a number).

3. Decide a volume of water to remove with the injector (making sure that the volume is appropriate for the container).

4. Place the injector source line into the container.

5. Turn on the injector and start the timer at the same time.

6. Stop the timer when the volume in the container reaches your predetermined level.

7. On paper, record injector setting, volume removed from the container, and the time elapsed.

8. Repeat this process for different dial settings.

9. Calculate the rate at which the injector operates (volume/ time) at each dial setting.

Results from the calibration of a nutrient injector are provided in Table 1.

Table 1. Examples of metering pump injector calibration results.

\begin{tabular}{|c|c|c|c|c|}
\hline \multirow{2}{*}{$\begin{array}{c}\text { Dial } \\
\text { setting }\end{array}$} & \multicolumn{2}{|c|}{ Calculated in the Field } & $\begin{array}{c}\text { Rate } \\
\text { (gal/min) }\end{array}$ & $\begin{array}{c}\text { Time (min) } \\
\text { to deliver } \\
\text { 5olume (gal) }\end{array}$ \\
\cline { 2 - 5 } & Time (min) & & 102 \\
\hline 2 & 0.5 & 10.2 & 0.05 & 65 \\
\hline 4 & 0.5 & 6.5 & 0.08 & 37 \\
\hline 8 & 0.5 & 3.7 & 0.14 & 13 \\
\hline 16 & 0.5 & 1.3 & 0.38 & \\
\hline
\end{tabular}




\section{Tip 4: Be very careful with units}

The units that are given with any product, such as $\mathrm{lb}, \mathrm{kg}$, gal, etc., should be carefully noted. Incorrect conversion between units or negligence and failure to use appropriate units can lead to chemigation mistakes. Some useful unit conversions are provided in Table 2.

Table 2. Quick reference for unit conversions.

\begin{tabular}{|l|l|}
\hline \multicolumn{1}{|c|}{ Length } & \multicolumn{1}{c|}{ Area } \\
\hline 1 inch $=2.54$ centimeters & 1 acre $=0.405$ hectares \\
\hline 1 foot $=0.305$ meters & 1 acre $=43,560$ square feet \\
\hline 1 foot $=30.48$ centimeters & 1 acre $=0.002$ square miles \\
1 yard $=0.914$ meters & 1 acre $=4046.86$ square meter \\
\hline 1 mile $=1.609$ kilometers & 1 acre $=4840$ square yard \\
\hline \multicolumn{1}{|c|}{ Volume } & \multicolumn{1}{c|}{ Mass } \\
\hline 1 pint $=0.473$ liters & 1 pound $=0.454$ kilograms \\
\hline 1 gallon $=0.134$ cubic feet & 1 ton $=907.185$ kilograms \\
\hline $\begin{array}{l}1 \text { fluid ounce }=29.57 \text { milliliters } \\
1 \text { pound/acre }=1.12 \text { kilograms/ } \\
\text { hectare }\end{array}$ \\
\hline $\begin{array}{l}1 \text { cubic inch }=16.39 \text { cubic } \\
\text { centimeters }\end{array}$ & 1 ounce $=28.35$ grams \\
\hline
\end{tabular}

\section{Tip 5: Use appropriate chemical and water combination}

In order to use the correct chemical and water combination, the irrigation pump rate and the recommended dilution (or concentration) must be determined. This information should be available from the chemical company or your local UF/IFAS Extension agent. An example calculation to determine the chemical injector setting is provided in Figure 3. Also, remember that some pesticides may not readily dissolve in water. If unsure of the solubility of a compound, check with the chemical supplier or your local Extension agent. Pesticides that are used and not soluble may accumulate in your system resulting in a blocked line.

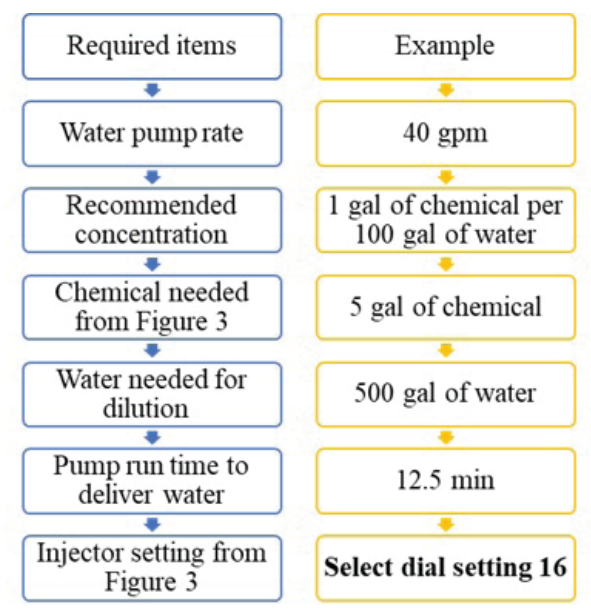

Figure 3. Example of steps for determining an appropriate injector setting. Calculation steps for amount of chemical needed are shown in Figure 2 above.
Tip 6: Keep your system in good condition

Routine maintenance is necessary for the proper operation of a chemigation system. Therefore, irrigation components need to be inspected regularly, and problems need to be fixed as they occur. When fixing irrigation parts, it is important that parts with the same specification should be used. A good method for checking the system is to turn on the irrigation and walk the field when field size is manageable. While walking through the field, look and listen for leaks. Most leaks will produce a whistling type sound and often an obvious puddle. Be sure to note that field inspection of irrigation components should be completed without the chemical injector operating. Another good idea for maintaining the system is to insert pressure gauges in the flow lines and check these gauges to detect problems in your system.

\section{Additional Precautions for Using Chemigation}

\section{Flush Irrigation System after Each Chemigation}

It is extremely important to flush the entire chemigation system, injection pump, strainer, hoses, and check valves with clean water after each chemigation. This is to ensure that no residual pesticides remain in the irrigation system. Flushing of the irrigation system must be done while the irrigation is on so that the flush solution with chemical residue is applied to the field.

\section{Maintain Optimal Water Pressure}

This is important to ensure that sprinklers work as expected and that water distribution is uniform and covers an area as per the specification. Extreme high-pressure produces mist or fog and wastes both water and chemicals during chemigation.

\section{Perform Regular Periodic Inspections of the Irrigation System}

Effectiveness of chemigation depends on a properly functioning irrigation system. Ensure that the spray pattern of the sprinkler or emitter is properly maintained, and repair any leaks or faulty sprinklers/emitters. Ensure that the spray pattern of the irrigation system doesn't go beyond the area of the target field. This is particularly important for center-pivot irrigation systems with end guns. Avoid chemigation by sprinkler system during strong winds, which can increase the water and chemicals lost to drift. The irrigation system must be managed to avoid runoff or 
deep percolation to minimize loss of water and chemicals offsite or below the root zone.

\section{Strictly Follow the Chemical Label}

Chemigation of a chemical that is labeled as not recommended for chemigation is strictly prohibited because this practice may adversely impact water quality, nontarget plants, and wildlife.

\section{Follow the Chemical Label for Mixing Chemicals}

Some pesticides are not compatible for mixing. Therefore, chemical label recommendations must be strictly followed to avoid mistakenly mixing pesticides that are not compatible.

\section{For More Information}

To learn more about chemigation, additional EDIS publications may be helpful. More detailed publications are available on chemigation and fertigation including but not limited to:

Clark, G. A., D. Z. Haman, and F. S. Zazueta. 2017. Injection of Chemicals into Irrigation Systems: Rates, Volumes and Injection Periods. BUL250. Gainesville: University of Florida Institute of Food and Agricultural Sciences. https://edis.ifas. ufl.edu/ae116.

DeValerio, J., D. Nistler, R. Hochmuth, and E. Simonne. 2018. Fertigation for Vegetables: A Practical Guide for Small Fields. Gainesville: University of Florida Institute of Food and Agricultural Sciences. HS1206. https:/edis.ifas.ufl.edu/ hs1206.

Haman, D. Z. 2017. Causes and Prevention of Emitter Plugging in Microirrigation Systems. BUL258. Gainesville: University of Florida Institute of Food and Agricultural Sciences. http://edis.ifas.ufl.edu/ae032.

Haman, D. Z., and F. S. Zazueta. 2017. Chemical Injection Methods for Irrigation. CIR864. Gainesville: University of Florida Institute of Food and Agricultural Sciences. http:// edis.ifas.ufl.edu/wi004.

Hochmuth, G., R. Mylavarapu, and E. Hanlon. 2019. The Four Rs of Fertilizer Management. SL411. Gainesville: University of Florida Institute of Food and Agricultural Sciences. http://edis.ifas.ufl.edu/ss624.
Liu, G., and G. K. England. 2018. How to Convert Liquid Fertilizer into Dry Fertilizer for Commercial Vegetable and Fruit Crop Production. HS1200. Gainesville: University of Florida Institute of Food and Agricultural Sciences. https:// edis.ifas.ufl.edu/hs1200.

Liu, G., K. Morgan, Y. Li, L. Zotarelli, Q. Wang, and J. DeValerio. 2019. What is $4 R$ nutrient stewardship? HS1264. Gainesville: University of Florida Institute of Food and Agricultural Sciences. https://edis.ifas.ufl.edu/hs1264.

Liu, G., E. H. Simonne, K. T. Morgan, G. J. Hochmuth, S. Agehara, and R. Mylavarapu. 2019. Chapter 2. Fertilizer Management for Vegetable Production in Florida. Gainesville: University of Florida Institute of Food and Agricultural Sciences. https://edis.ifas.ufl.edu/cv296.

Zotarelli, L., M. D. Dukes, G. Liu, E. H. Simonne, and S. Agehara. 2019. Chapter 3. Principles and Practices of Irrigation Management for Vegetables. CV297. Gainesville: University of Florida Institute of Food and Agricultural Sciences. https://edis.ifas.ufl.edu/cv297.

\section{References}

Haman, D. Z. 2017. Causes and Prevention of Emitter Plugging in Microirrigation Systems. BUL258. Gainesville: University of Florida Institute of Food and Agricultural Sciences. https://edis.ifas.ufl.edu/ae032.

Haman, D. Z., and F. S. Zazueta. 2017. Chemical Injection Methods for Irrigation. CIR864. Gainesville: University of Florida Institute of Food and Agricultural Sciences. https://edis.ifas.ufl.edu/wi004. 